\title{
In vitro Performance of Two Banana Cultivars Under Copper Stress
}

\author{
Pisam, W.M. ${ }^{1}$; A.H. Abdel Aal ${ }^{1}$; O.A. Khodair ${ }^{1}$ and M. Youssef ${ }^{2} \bigcirc{ }^{\text {CrossMark }}$ \\ ${ }^{1}$ Department of Horticulture, Faculty of Agriculture, Al-Azhar University, Assiut, \\ Egypt \\ 2 Department of Genetics, Faculty of Agriculture, Assiut University, Egypt \\ Received on: $14 / 6 / 2020$ \\ Accepted for publication on: 20/6/2020
}

\begin{abstract}
Environmental pollution is one of the most issues directly or indirectly affecting human life. Heavy metals are considered as the most environmental pollutants affecting plant growth and productivity. Thus, herein the toxicity of copper on in vitro growth and development of two banana commercial cultivars i.e. 'Grand Nain' and 'WilliamsZeef' was assessed. Six concentrations of cupric sulfate were used in banana proliferation medium, i.e. 0, 100, 200, 500, 1000 and 1500ppm. Results clearly showed the harmful effect of copper on banana performance reflected by a significant reduction in survival rate, leaf number, fresh and dry weights as well as a complete inhibition of root formation at higher concentrations. Furthermore, excess of copper was able to reduce photosynthetic pigments contents (chlorophyll-A, -B and carotenoids). The two banana cultivars were affected differently under copper levels. In general, 'Williams-Zeef' was more tolerant than 'Grand Nain' as exposed by less reduction in both morphological and physiological characteristics. In vitro screening protocol used in this investigation was easy, simple, inexpensive and reduces time and space which are regularly needed to achieve such tasks. With which it was easily to figure out the harmful effect of copper and clearly differentiate between the tested banana cultivars. The results of this study could help in banana improvement by selecting the proper genotypes to be used in copper-contaminated soils, after increasing the number of screened cultivars.
\end{abstract}

Keywords: Musa, Environmental pollution, In vitro screening, Heavy metals

\section{Introduction:}

Banana (Musa spp.) is one of the most important fruit crops cultivated in tropical and subtropical regions of the world. It contributes to the food security of millions of people in the developing countries (Bakry et al., 2009). It is grown in every humid tropical region and constitutes the $4^{\text {th }}$ largest fruit crop worldwide. Banana production occupies an important share in the total fruit of Egypt. The annual production of banana by about 120 countries is about 106.7 million tons (FAO, 2015). In Egypt, the total cultivated area of banana in 2009 was about 2700 ha (about 6480 fed.) with a pro- duction of about $1,100,000$ tons (FAO, 2009).

Banana is one of the best choices for new reclaimed lands such Sinai and Western desert. However, it faces several abiotic stresses including drought, salinity and heavy metals. Heavy metal pollution is one of the most troublesome environmental problems faced by plant species. Copper poses serious problems due to its widespread industrial and agricultural use (Fernandes and Henriques, 1991). It is an essential micronutrient for normal plant growth and constitutes of the protein component of several enzymes in plants, mainly those participating in electron flow, catalyzing redox reactions in mito- 
chondriar chloroplasts, cell wall and cytoplasm of plant cells (Lolkema, 1985). However، exposure to high concentration of copper can cause a broad range of deleterious effects such as inhibition of photosynthesis, damage to plasma membrane permeability as well as other metabolic disturbances, either in field plants (Lanaras et al., 1993؛ Ouzounidou et al., 1993) or in vitro grown plants (Gori et al., 1998; Romeu-Moreno and Mas, 1999). The content of total and available copper in the Egyptian soils is in increase due to irrigation with sewage water in some areas and the intensive use of pesticides, which have a noticeable content of heavy metals. Copper status in Egyptian lands varied depending on geographic location, however it exceeded $100 \mathrm{ppm}$ in some areas (El-Sayed, 1988). This concentration could be increased by 6.78 times in soils irrigated with sewage water as compared to non-irrigated soils (Selem et al., 2000).

Plant tissue culture technique provides an easy controlled system for stress screening. These in vitro systems decrease the environmental factors affecting screening and provide controlled tool with symmetrical balance of stress application (Errabii et al., 2006). Moreover, tissue culture-based screening has the simplicity to manipulate large number of plants and stress treatments with a limit space and in a short time (Misra et al., 2002; Abouzaid et al., 2016; Elazab and Youssef, 2017)

In vitro assessment of copper toxicity on plant growth and development has been achieved in several plant species, including Nicotiana ta- bacum (Gori et al., 1998), tomato (ElAref and Hamada, 1998), Citrus reticulata (Chakravarty and Goswami, 2000), Alianthus altissima (Gatti, 2008) and date palm (AL-Mayahi, 2014). However, a limit number of investigations is available on the effect of copper toxicity on banana (Nassar, 2004; Deo and Nayak, 2011). Therefore, the aim of the present study was to assess the in vitro performance of two banana commercial cultivars, i.e. 'Grand Nain' and 'Williams-Zeef' under different levels of copper.

\section{Materials and Methods:}

\subsection{Plant Materials and in vitro conditions}

In vitro regenerated plantlets of 'Grand Nain' and 'Williams-Zeef' banana commercial cultivars (Musa acuminata Colla, subgroup Cavendish) were obtained from the private Zamzam Tissue Culture Laboratory, Cairo, Egypt. Plantlets were subcultured three times at an interval of 30 days. The proliferation culture media consisted of the full strength MS medium (Murashige and Skoog, 1962) supplemented with $22 \mu \mathrm{M} 6-$ benzyleaminopurine (BAP), $30.0 \mathrm{~g} / \mathrm{L}$ sucrose and solidified with $2.0 \mathrm{~g} / \mathrm{L}$ gelrite. The cultures were incubated at $26^{\circ} \mathrm{C} \pm 1{ }^{\circ} \mathrm{C}$ under $16 \mathrm{hr}$ light regime.

\subsection{Copper treatment}

After the third subculture, banana plantlets were transferred to full MS medium with the following treatments: 100, 200, 500, 1000 and $1500 \mathrm{ppm} \mathrm{CuSO}_{4} .5 \mathrm{H}_{2} \mathrm{O}$ with a control of copper free medium. All media were supplemented with $30.0 \mathrm{~g} / \mathrm{L}$ sucrose and $2.0 \mathrm{~g} / \mathrm{L}$ gelrite. Cultures were incubated as described above. 


\subsection{Morphophysiological evalua- tion}

After 5 weeks of treatment, plantlets were harvested, and some measurements were recorded on proliferated plantlets. Those included survival percentage, leaf number $(\mathrm{LN})$, root number $(\mathrm{RN})$, fresh $(\mathrm{FW}$, g) and dry weight (DW, g) and copper uptake (mg/g DW). In addition, photosynthetic pigments contents (mg/g FW), i.e. chlorophyll-A, -B and carotenoids were estimated spectrophotometrically according to Lichtenthaler (1987).

\subsection{Data analysis}

A complete randomized design was used to perform the experiment. Three replicates with 4 jars each were used per treatment. Analysis of variance was performed utilizing MSTAT-C statistical program (Nissen, 1984). Means were compared using Duncan's least range test at $1 \%$ probability level.

\section{Results and Discussion}

Copper is an essential micronutrient for normal plant growth and metabolism. It plays a vital role in many metallo enzymes, photosynthesis-related plastocyanin, and membrane structure (Li and Xiong, 2004). However, when it exists in a high concentration, copper inhibits plant growth and seed germination, induces chlorophyll degradation, and interferes with photosystem activity (Caspi et al., 1999).

In the present study, the toxic effect of copper on in vitro performance of the two banana cultivars (i.e.
'Grand Nain' and 'Williams-Zeef') was evaluated. Results showed that copper affected all the morphological and physiological characteristics in both cultivars. However, 'WilliamsZeef' was - in general - more tolerant than 'Grand Nain', reflected by lower reduction in the most evaluated parameters. Analysis of variance showed highly significant differences due to the different copper concentrations compared to control in all studied traits (Table 1). On the other hand, among the morphological traits, the two cultivars showed highly significant effect in all evaluated characteristics except leaf and root numbers.

Regarding the morphological traits, the survival rate was affected in both cultivars in a different manner compared to control, No difference was detected due to $100 \mathrm{ppm}$ copper in both cultivars. Particularly, in 'Grand Nain', the significant reduction in survival rate began from the concentration $500 \mathrm{ppm}$ in which it reached $64.3 \%$. Moreover, the highest level of copper (1500ppm) was enough to reduce the survival rate with $68.7 \%$ compared with control (Table 2). On the other hand, although the survival rate was gradientaffected in 'Williams-Zeef' through the successive increased levels of copper, No significant differences were observed in all treatments compared to control. This result clearly reflected the difference of the two cultivars in their response to the toxic effect of copper. 
Table 1. Analysis of variance of the in vitro performance of two banana cultivars under different levels of copper.

\begin{tabular}{|c|c|c|c|}
\hline Trait & Source of variance & df & Means of squares \\
\hline \multirow{4}{*}{ Survival rate } & Cultivars (A) & 1 & $0.283 * *$ \\
\hline & Copper concentrations (B) & 5 & $0.239 * *$ \\
\hline & $\mathrm{A} \times \mathrm{B}$ & 5 & $0.047 *$ \\
\hline & Error & 24 & 0.016 \\
\hline \multirow{4}{*}{ Leaf number } & Cultivars (A) & 1 & $0.124^{\mathrm{NS}}$ \\
\hline & Copper concentrations (B) & 5 & $19.890 * *$ \\
\hline & $\mathrm{A} \times \mathrm{B}$ & 5 & $0.542 *$ \\
\hline & Error & 24 & 0.200 \\
\hline \multirow{4}{*}{ Root number } & Cultivars (A) & 1 & $0.281^{\mathrm{NS}}$ \\
\hline & Copper concentrations (B) & 5 & $37.320 * *$ \\
\hline & $\mathrm{A} \times \mathrm{B}$ & 5 & $0.336^{\mathrm{NS}}$ \\
\hline & Error & 24 & 0.411 \\
\hline \multirow{4}{*}{ Fresh weight } & Cultivars (A) & 1 & $0.412 * *$ \\
\hline & Copper concentrations (B) & 5 & $2.116^{* *}$ \\
\hline & $\mathrm{A} \times \mathrm{B}$ & 5 & $0.010^{\mathrm{NS}}$ \\
\hline & Error & 24 & 0.034 \\
\hline \multirow{4}{*}{ Dry weight } & Cultivars (A) & 1 & $0.004 * *$ \\
\hline & Copper concentrations (B) & 5 & $0.012 * *$ \\
\hline & $\mathrm{A} \times \mathrm{B}$ & 5 & $0.001^{\mathrm{NS}}$ \\
\hline & Error & 24 & 0.00001 \\
\hline \multirow{4}{*}{$\mathrm{Cu}$ uptake } & Cultivars (A) & 1 & $5.048 * *$ \\
\hline & Copper concentrations (B) & 5 & $202.227 * *$ \\
\hline & $\mathrm{A} \times \mathrm{B}$ & 5 & $9.156^{* *}$ \\
\hline & Error & 24 & 0.606 \\
\hline \multirow{4}{*}{ Chlorophyll-A } & Cultivars (A) & 1 & $0.010^{*}$ \\
\hline & Copper concentrations (B) & 5 & $0.490 * *$ \\
\hline & $\mathrm{A} \times \mathrm{B}$ & 5 & $0.027 * *$ \\
\hline & Error & 24 & 0.002 \\
\hline \multirow{4}{*}{ Chlorophyll-B } & Cultivars (A) & 1 & $0.024 * *$ \\
\hline & Copper concentrations (B) & 5 & $0.015 * *$ \\
\hline & $\mathrm{A} \times \mathrm{B}$ & 5 & $0.001 *$ \\
\hline & Error & 24 & 0.00001 \\
\hline \multirow{4}{*}{ Carotenoids } & Cultivars (A) & 1 & $0.001^{\mathrm{NS}}$ \\
\hline & Copper concentrations (B) & 5 & $0.076^{* *}$ \\
\hline & $\mathrm{A} \times \mathrm{B}$ & 5 & $0.003 * *$ \\
\hline & Error & 24 & 0.00001 \\
\hline
\end{tabular}

The number of leaves (LN) and roots $(\mathrm{RN})$ in the two evaluated cultivars was almost the same at control. Copper treatments affected LN and $\mathrm{RN}$ significantly in both cultivars starting from the lowest concentration (100ppm) with a reduction of 45.49 and $53.03 \%$ in 'Grand Nain' and 'Williams-Zeef' respectively (Table 2). Moreover, copper levels were 
enough to prevent rooting completely in both cultivars initiated from 200ppm (Table 2). In addition, all evaluated concentrations of copper significantly affected the fresh and dry weight in both cultivars. However, no significant differences were observed between the two cultivars, which indicate that both cultivars showed the same response to copper in these traits. The effect of copper toxicity on in vitro growth of the two banana cultivars is shown in Figure (1).

Table 2. Averages of some morphological characteristics of two banana cultivars under different levels of copper.

\begin{tabular}{|c|l|c|c|c|c|c|c|}
\hline \multirow{2}{*}{ Trait } & \multirow{2}{*}{ Cultivar } & \multicolumn{7}{|c|}{ Copper concentration (ppm) } \\
\cline { 3 - 8 } & & Control & $\mathbf{1 0 0}$ & $\mathbf{2 0 0}$ & $\mathbf{5 0 0}$ & $\mathbf{1 0 0 0}$ & $\mathbf{1 5 0 0}$ \\
\hline \multirow{2}{*}{ SR (\%) } & GN & $100 \pm 0.00^{\mathrm{A}}$ & $100 \pm 0.00^{\mathrm{A}}$ & $86.70 \pm 13.33^{\mathrm{AB}}$ & $64.3 \pm 15.67^{\mathrm{BC}}$ & $46.7 \pm 7.13^{\mathrm{CD}}$ & $31.3 \pm 8.67^{\mathrm{D}}$ \\
\cline { 2 - 8 } & Zeef & $100 \pm 0.00^{\mathrm{A}}$ & $100 \pm 0.00^{\mathrm{A}}$ & $94.3 \pm 5.67^{\mathrm{AB}}$ & $87.7 \pm 6.23^{\mathrm{AB}}$ & $82.0 \pm 1.00^{\mathrm{AB}}$ & $71.3 \pm 4.33^{\mathrm{ABC}}$ \\
\hline \multirow{2}{*}{ LN } & GN & $5.65 \pm 0.24^{\mathrm{A}}$ & $3.08 \pm 0.37^{\mathrm{B}}$ & $1.67 \pm 0.35^{\mathrm{CDE}}$ & $0.64 \pm 0.16^{\mathrm{EF}}$ & $0.47 \pm 0.07^{\mathrm{F}}$ & $0.31 \pm 0.09^{\mathrm{F}}$ \\
\cline { 2 - 8 } & Zeef & $5.11 \pm 0.39^{\mathrm{A}}$ & $2.40 \pm 0.20^{\mathrm{BC}}$ & $1.80 \pm 0.32^{\mathrm{CD}}$ & $1.04 \pm 0.23^{\mathrm{DEF}}$ & $1.14 \pm 0.23^{\mathrm{DEF}}$ & $1.02 \pm 0.21^{\mathrm{DEF}}$ \\
\hline \multirow{2}{*}{ RN } & GN & $6.75 \pm 0.38^{\mathrm{A}}$ & $0.39 \pm 0.24^{\mathrm{B}}$ & $0.00 \pm 0.00^{\mathrm{B}}$ & $0.00 \pm 0.00^{\mathrm{B}}$ & $0.00 \pm 0.00^{\mathrm{B}}$ & $0.00 \pm 0.00^{\mathrm{B}}$ \\
\cline { 2 - 8 } & Zeef & $5.61 \pm 1.17^{\mathrm{A}}$ & $0.47 \pm 0.24^{\mathrm{B}}$ & $0.00 \pm 0.00^{\mathrm{B}}$ & $0.00 \pm 0.00^{\mathrm{B}}$ & $0.00 \pm 0.00^{\mathrm{B}}$ & $0.00 \pm 0.00^{\mathrm{B}}$ \\
\hline \multirow{2}{*}{ FW } & GN & $2.23 \pm 0.26^{\mathrm{A}}$ & $0.98 \pm 0.08^{\mathrm{B}}$ & $0.87 \pm 0.04^{\mathrm{B}}$ & $0.72 \pm 0.15^{\mathrm{B}}$ & $0.76 \pm 0.01^{\mathrm{B}}$ & $0.68 \pm 0.05^{\mathrm{B}}$ \\
\cline { 2 - 8 } & Zeef & $2.05 \pm 0.14^{\mathrm{A}}$ & $0.61 \pm 0.05^{\mathrm{B}}$ & $0.64 \pm 0.07^{\mathrm{B}}$ & $0.56 \pm 0.06^{\mathrm{B}}$ & $0.56 \pm 0.04^{\mathrm{B}}$ & $0.54 \pm 0.02^{\mathrm{B}}$ \\
\hline \multirow{2}{*}{ DW } & GN & $0.180 \pm 0.01^{\mathrm{A}}$ & $0.083 \pm 0.00^{\mathrm{C}}$ & $0.080 \pm 0.00^{\mathrm{D}}$ & $0.073 \pm 0.01^{\mathrm{E}}$ & $0.05 \pm 0.00^{\mathrm{F}}$ & $0.04 \pm 0.00^{\mathrm{G}}$ \\
\cline { 2 - 8 } & Zeef & $0.14 \pm 0.01^{\mathrm{B}}$ & $0.05 \pm 0.01^{\mathrm{F}}$ & $0.05 \pm 0.00^{\mathrm{F}}$ & $0.05 \pm 0.01^{\mathrm{F}}$ & $0.05 \pm 0.00^{\mathrm{F}}$ & $0.04 \pm 0.00^{\mathrm{H}}$ \\
\hline \multirow{2}{*}{ Cu uptake } & GN & $1.04 \pm 0.04^{\mathrm{I}}$ & $4.35 \pm 0.21^{\mathrm{H}}$ & $6.41 \pm 0.35^{\mathrm{F}}$ & $11.11 \pm 0.63^{\mathrm{D}}$ & $13.00 \pm 0.05^{\mathrm{C}}$ & $19.73 \pm 0.43^{\mathrm{A}}$ \\
\cline { 2 - 8 } & Zeef & $4.35 \pm 0.24^{\mathrm{H}}$ & $4.57 \pm 0.29^{\mathrm{GH}}$ & $6.22 \pm 0.91^{\mathrm{FG}}$ & $9.05 \pm 0.56^{\mathrm{E}}$ & $9.13 \pm 0.42^{\mathrm{E}}$ & $17.82 \pm 0.46^{\mathrm{B}}$ \\
\hline
\end{tabular}

Values represent means \pm standard error, SR: survival rate, LN: leaf number, RN: root number, FW: fresh weight, DW: dry weight, GN: 'Grand Nain' and Zeef: 'Williams-Zeef'. Different letters in the same trait indicate significance based on Duncan's test $(\alpha=0.05, \mathrm{n}=3)$.

The effect of in vitro toxicity of copper on banana growth and development has been studied in a limit number of investigations. In this regard, in accordance with our results high level of $\mathrm{CuSO}_{4}(100 \mu \mathrm{M})$ showed toxic effect on banana leaves and completely inhibited root formation (Nassar, 2004). Moreover, the effect of different concentrations of copper on growth and development of Musa acuminata has been assessed (Deo and Nayak, 2011). Matching with the findings of the current study, the authors found that higher level of copper $(100 \mu \mathrm{M})$ showed toxic effect on banana dry matter, shoot and root growth, as well as it completely inhibited root formation. 

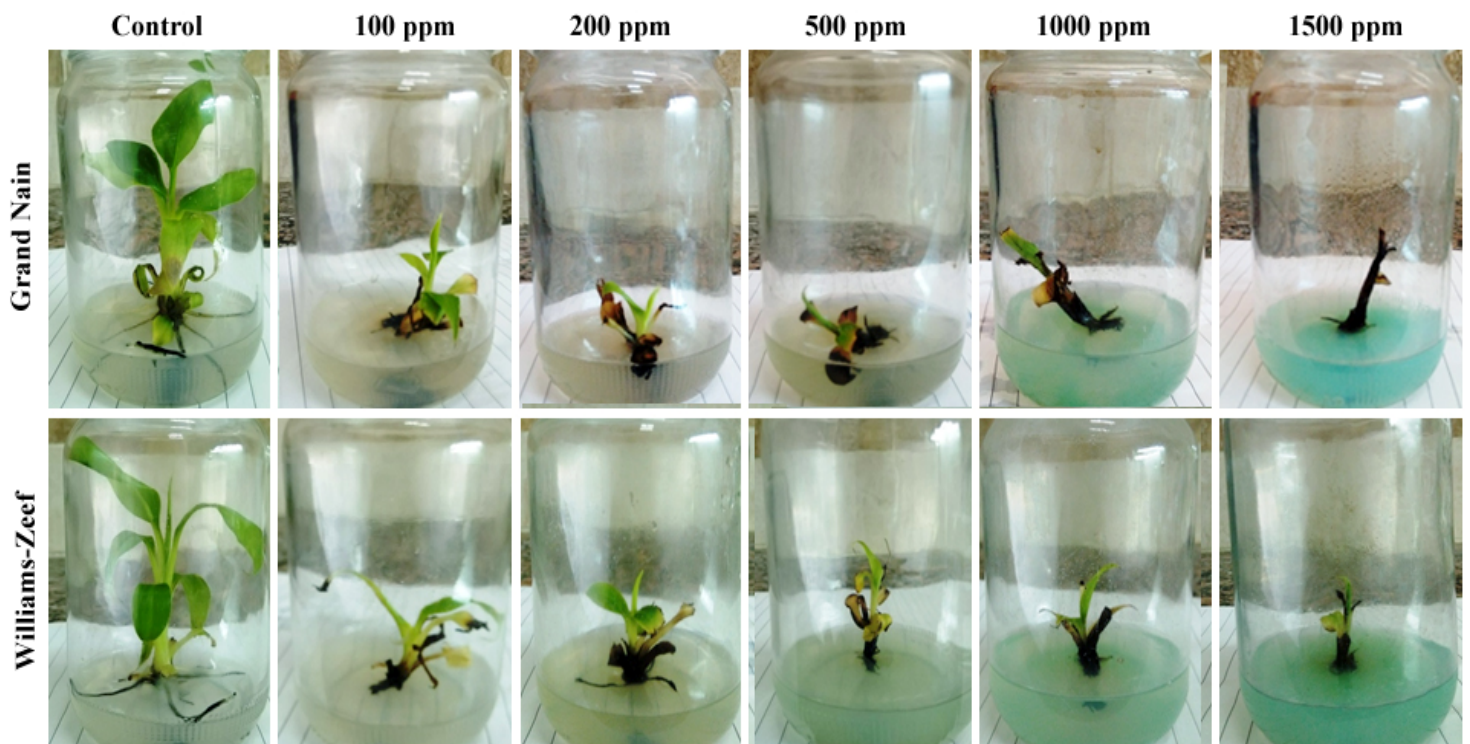

Figure (1): In vitro performance of two banana cultivars under different concentrations of copper.

Additionally, the toxic effect of copper has been assessed in vitro in several plant species. In this regard, Gori et al., (1998) reported that in vitro copper treatment with a concentration higher than $50 \mu \mathrm{M}$ was enough to inhibit callus growth and shoot regeneration in Nicotiana tabacum. Moreover, copper was toxic to tomato explants at $100 \mu \mathrm{M}$, it caused a reduction in callus growth and shoot regeneration. In addition, copper reduced the expression of some enzymatic bands of alcohol dehydrogenase and esterase (El-Aref and Hamada, 1998). Matching with our findings, Chakravarty and Goswami, (2000) reported that, high copper concentrations affected root growth more than shoot growth and inhibited the increase in fresh and dry weight of in vitro cultures of Citrus reticulata. Gatti, (2008) studied the in vitro tolerance of Alianthus altissima to some heavy metals including copper, they reported that shoot growth was reduced at higher copper concentrations. Furthermore, in date palm, rela- tive low concentration of copper $(8 \mu \mathrm{M})$ was enough to reduce several morphological traits including shoot formation, number of shoots per callus, rooting percentage, number of roots and length of plant and root. In addition, other physiological characteristics were also reduced including the content of carbohydrates, total protein, total phenol and chlorophyll (AL-Mayahi, 2014).

Copper uptake was measured in the present study in both cultivars after the different treatments. Results showed that, the concentration of copper in plant tissue through all treatments was higher in 'Grand Nain' than that in 'Williams-Zeef' (Table 2). This result may explain the different performance of the two cultivars and their different response under copper treatments.

Furthermore, the content of photosynthesis related pigments (i.e. chlorophyll-A, -B and carotenoid) was detected in both cultivars under control and different copper levels. Results herein clearly showed the 
harmful effect of copper on the content of these pigments. In this regard, analysis of variance showed significant differences between the two banana cultivars in all photosynthesis traits except carotenoid content (Table 1). In addition, ANOVA exhibited highly significant differences between copper different levels and control. The more concentration of copper the more reduction was found in chlorophyll-A and -B (Figure 2). Copper treatment under all its con- centrations significantly affected the carotenoid content in both cultivars compared with control. Interestingly, among copper levels, the concentration of 500ppm gave the highest content of carotenoids (Figure 2). In addition, 'Williams-Zeef' - generally showed more tolerance than 'Grand Nain' reflected by less reduction in the content of photosynthesis related pigments under different copper concentrations (Figure 2).

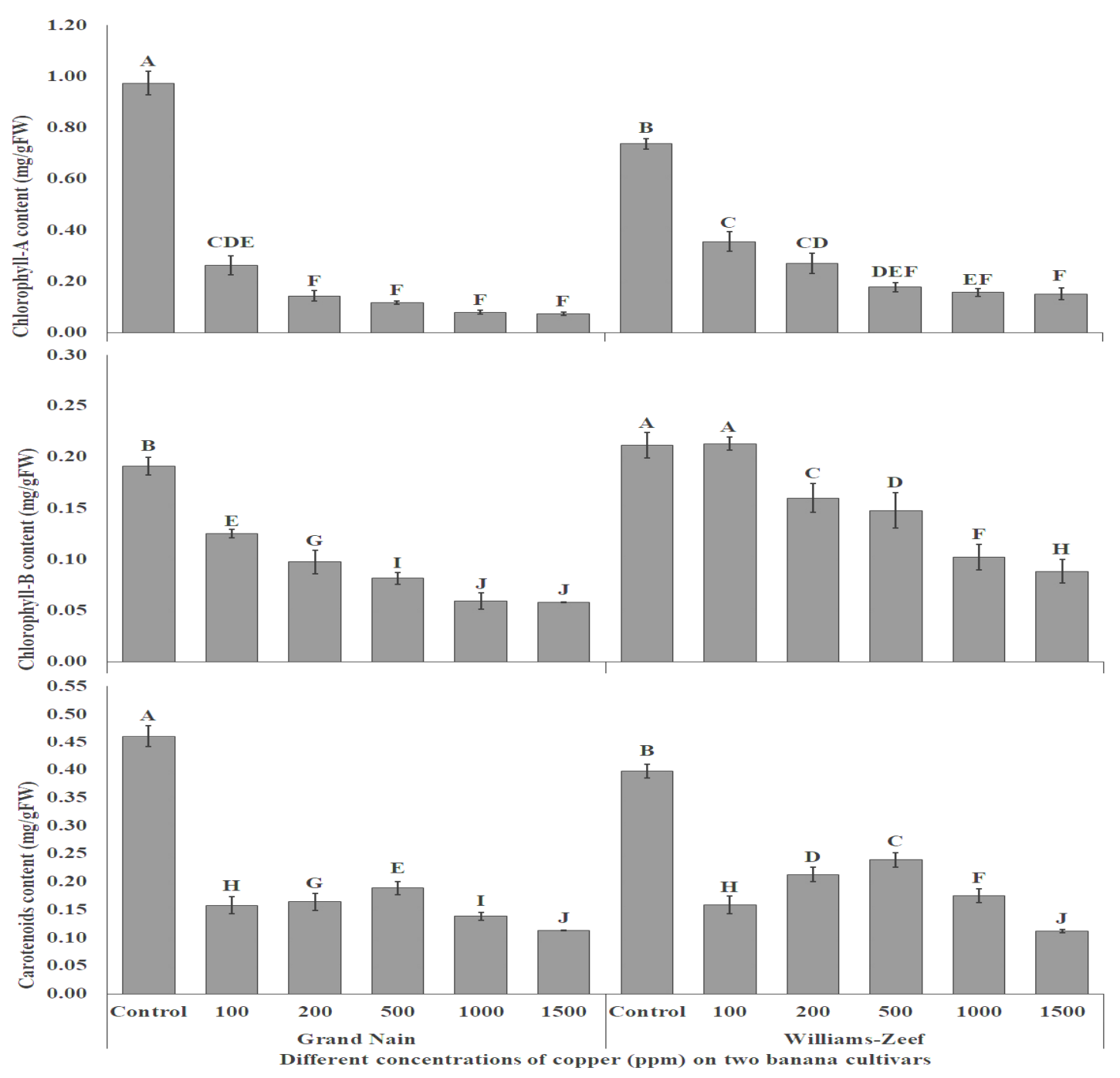

Figure (2): Averages of photosynthetic pigments content; upper: chlorophyll-A, middle: chlorophyll-B and lower: carotenoids, of two banana cultivars under different copper concentrations. Different letters in the same trait indicate significance at 0.01 probability level, Duncan's test $(\mathrm{n}=3)$. 
Excess copper inhibits many enzymes and interferes with several aspects of plant biochemistry, including photosynthesis, pigment synthesis, and membrane integrity (Fernandes and Henriques, 1991). Matching with our findings, copper induces chlorophyll degradation, and interferes with photosystem activity (Caspi et al., 1999). In addition, photosynthetic pigments contents in banana were increased under lower levels of copper; however, they were significantly reduced under high concentration, compared to control (Deo and Nayak, 2011). Unlike our results, Gori et al., (1998) did not found any differences in chlorophyll contents or chloroplast structure in tobacco due to in vitro copper treatments as compared with control. However, they used lower concentration $(100 \mu \mathrm{M})$ than what has been used in the current study.

In conclusion, this investigation clearly showed the harmful and toxic effect of copper on banana in vitro growth and development. Excess of copper in culture medium was able to reduce survival rate, leaf number, fresh and dry weight and completely inhibited root formation. Moreover, photosynthetic pigments contents were also reduced significantly due to copper toxicity. Although both cultivars tested in the present study have been affected by copper stress, 'Williams-Zeef' was in general more tolerant than 'Grand Nain'. Unlike previous investigations, the extreme high concentrations of copper used herein were helpful to differentiate between the two banana cultivars and draw a good explanation about how banana tolerate copper stress in vitro. These findings could help in selecting tolerant genotypes of banana after increasing the number of screened cultivars to choose the proper for copper contaminated soil.

\section{References:}

Abouzaid, E, El-Sayed EN, Mohamed EA, Youssef M (2016). Molecular analysis of drought tolerance in guava based on in vitro PEG evaluation. Tropical plant biology, 9(2), 73-81.

Al-Mayahi AMW (2014). Effect of copper sulphate and cobalt chloride on growth of the in vitro culture tissues for date palm (Phoenix dactylifera L.) cv. Ashgar. American Journal of Agricultural and Biological Sciences, 9(1), 6-18.

Bakry, F, Careel F, Jenny C, Horry JP (2009). Genetic improvement of banana. In SM Jain and PM Priyadarshan (Eds.), Breeding plantation tree crops: tropical species (pp. 3-50). New York: Springer Science and Business Media.

Capsi, V, Droppa M, Horváth G, Malkin S, Marder JB, Raskin VI (1999). The effect of copper on chlorophyll organization during greening of barley leaves. Photosynth Res 62:165-174.

Chakravarty, B and Goswami BC (2000). Effect of zinc and copper on growth and regenerating cultures of Citrus reticulata Blanco. Indian Journal of Plant Physiology 5.1: 52-58.

Deo, B, Nayak PK (2011). Study of copper phytotoxicity on in vitro culture of Musa acuminata cv. Bantala. Journal of Agricultural Biotechnology and Sustainable Development, 3(8), 136-140.

El-Aref, HM, Hamada, AM (1998). Genotypic differences and alterations of protein patterns of tomato 
explants under copper stress. Biologia plantarum, 41(4), 555564.

Elazab, DS, Youssef M (2017). In vitro Response of Some Banana Cultivars to Salicylic AcidTreatment Under Salinity Stress. Assiut Journal of Agricultural Sciences, 48(4), 168-184.

El-Sayed, EA (1988). Status of some trace elements in relation to the nature of the main sediments in the Fayoum (Egypt) Depression. Ph.D. Thesis, Dept. of Soil Sci., Aberdeen Univ., Scotland, U.K.

Errabii, T, Gandonou CB, Essalmani $\mathrm{H}$, Abrini J, Idaomar M, Skali-Senhaji N (2006). Growth, proline and ion accumulation in sugarcane callus cultures under drought-induced osmotic stress and its subsequent relief. African Journal of Biotechnology, 5(16).

FAOSTAT (2009). Food and Agriculture Organization of the United Nations. http://faostat.fao.org.

FAOSTAT (2015). Food and Agriculture Organization of the United Nations. http://faostat.fao.org.

Fernandes, JC, Henriques FS (1991). Biochemical, physiological, and structural effects of excess copper in plants. The Botanical Review, 57(3), 246-273.

Gatti, E (2008). Micropropagation of Ailanthus altissima and in vitro heavy metal tolerance. Biologia Plantarum, 52(1), 146-148.

Gori, P, Schiff S, Santandrea G, Bennici A (1998). Response of shape in vitro cultures of shape Nicotiana tabacum L. to copper stress and selection of plants from Cu-tolerant callus. Plant cell, tissue and organ culture, 53(3), 161-169.

Lanaras, T, Moustakas M, Symeonidis L, Diamantoglou S, Karataglis S (1993). Plant metal content, growth responses and some photo- synthetic measurements on fieldcultivated wheat growing on ore bodies enriched in $\mathrm{Cu}$. Physiol. Plant., 88: 307-14.

Li T, Xiong Z (2004). A novel response of wild $\square$ type duckweed (Lemna paucicostata Hegelm.) to heavy metals. Environmental Toxicology: An International Journal, 19(2), 95-102.

Lichtenthaler, HK (1987). Chlorophylls and carotenoids: Pigments of photosynthetic biomembranes. Methods in Enzymology 148, 350-382.

Lolkema, PC (1985). Copper resistance in higher plants. Ph.D. Thesis, Free Univ. Press, Amesterdam.

Misra, AN, Biswal AK, Misra M (2002). Physiological, biochemical and molecular aspects of water stress responses in plants, and the biotechnological applications. Proceedings-National Academy of Sciences India Section B, 72(2), $115-134$

Murashige, T, Skoog F (1962). A revised medium for rapid growth and bioassay with tobacco tissue culture. Physiol.plant. 15:473-497.

Nassar, AH (2004). Effect of some copper compounds on rhizogenesis of micropropagated banana shoots. International Journal of Agriculture \& Biology, 6(3), 552-556.

Nissen, O, Riley H, Skjelvag AO (1984). MSTAT. A microcomputer program for statistical analyses of experiments and surveys. The impact of climate on grass production and quality. Proc GeneralMeet EurGrassl Fed, $10^{\text {th }}$, As, Norway. 2630 June 1984. Norwegian State Agric. Res. Stations, As, pp. 555559.

Ouzounidou, G, Lannoye R, Karataglis S (1993). Photoacoustic measurements of photosynthetic activities in intact leaves under copper stress. Plant Sci., 89: 221-6. 
Romeu-Moreno A, Mas A (1999). Effect of copper exposure in tissue cultured Vitis vinifera. J. Agric. Chem., 47: 2519-22.

Selem, MM, El-Amir S, Abd-Elaziz SM, Kandil MF, Mansour SF (2000).
Effect of irrigation with sewage water on some chemical characteristics of soils and plants. Egypt. J. Soil Sci., 40: 49-59. 
تقييم أداء صنفين من الموز معملياً تحت ظروف إجهاد النحاس إساس

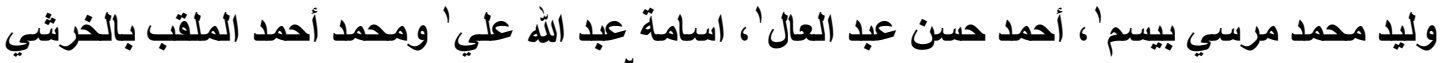

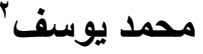

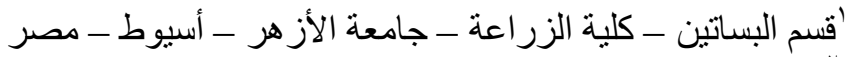

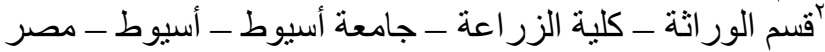

الملخص

يعتبر التلوث البيئي أحد أهم العو امل التي تؤثر سلباً على حياة الانسان بطريقة مباشرة أو

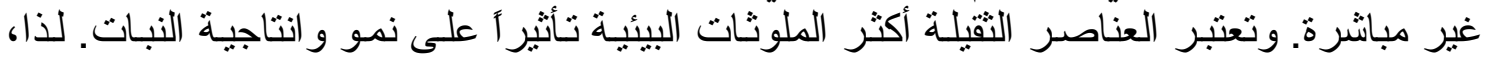

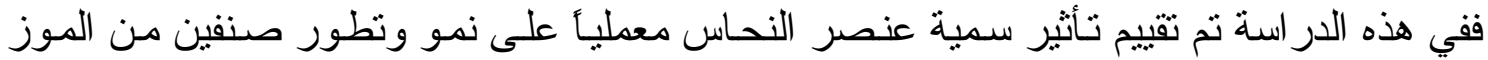

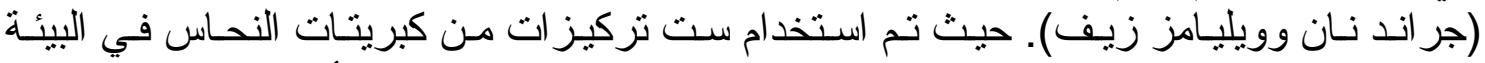

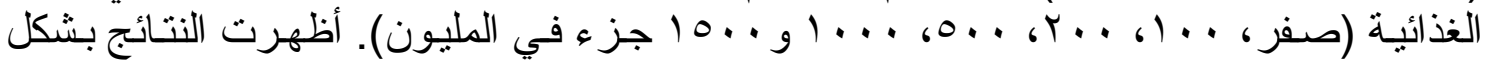

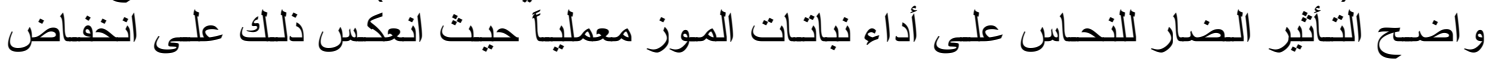

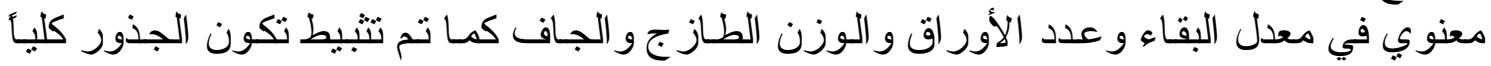
تحت التركيز ات المرتفعة. بالإضافة لذلك، فقد سبب مستوى النحاس في البيئة على تقليل محتوى

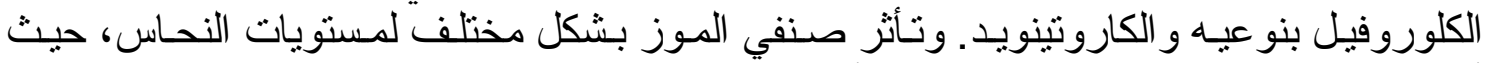

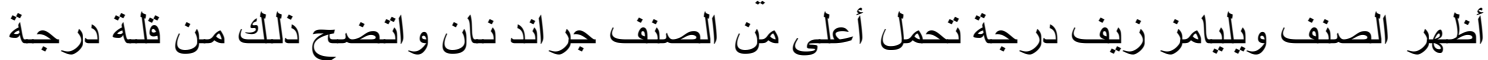

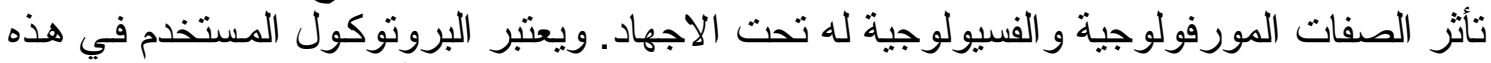

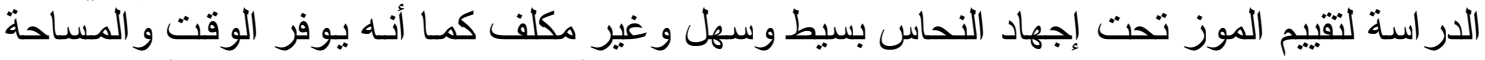

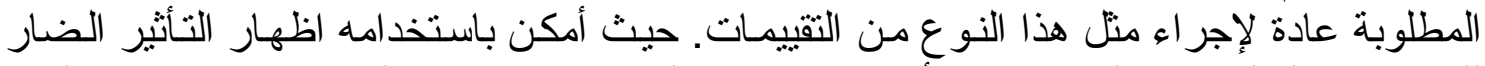

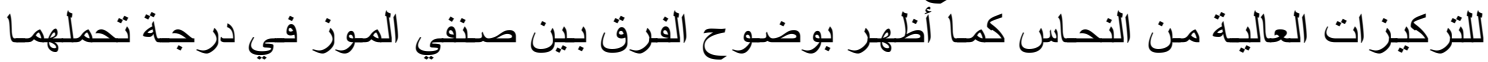

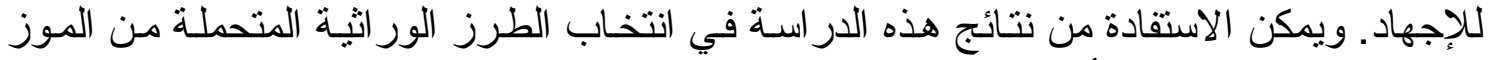

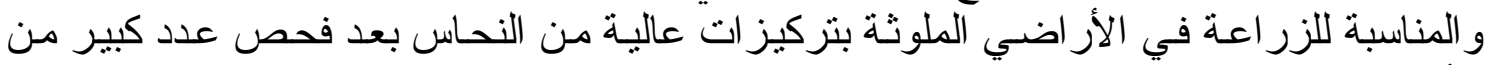

